CONTROL OF TUBERCULOSIS

\title{
IMPORTANCE OF HEREDITY AND ENVIRONMENT
}

\author{
BY \\ A. W. ANDERSON,* B. BENJAMIN, R. GRENVILLE-MATHERS, \\ AND H. J. TRENCHARD \\ From the Harrow and Edgware Chest Clinics, Middlesex
}

\section{INTRODUCTION}

From many standpoints, but especially that of planning public health measures, it is important to know whether the development of manifest tuberculous disease depends principally upon the inherent susceptibility of the individual, or whether the factors of dosage of bacilli, exposure to infection, and fluctuations in resistance determined by environmental conditions outweigh in importance any influence that may be exerted by heredity. All physicians treating tuberculosis know of families with a high incidence of the disease, and it has seemed probable to them that in some instances the influence of heredity may be decisive. The question is important because we can do little to influence heredity whereas it may be possible to control the other factors.

Animal experiments support the idea that there is an hereditary resistance to the development of tuberculosis. Wright and Lewis (1921), working on guinea pigs, the progeny of brother-sister matings carried out for many generations, found marked differences in resistance to experimental infection. As shown by the length of life after inoculation with tubercle bacilli, some offspring had a greater resistance to the disease than did their parents, and these differences could be maintained for several generations. This work was continued by Lurie (1941), who used eight rabbit families all having a common ancestor. The animals were exposed in cages to rabbits which had been infected intravenously with virulent tubercle bacilli. Such a procedure produced a chronic type of disease, the urine being the main source of infection. The lungs of the contact rabbits were $x$-rayed every month and it was found that these rabbit families fell into three groups:

(1) those developing chronic disease;

(2) those developing rapidly progressive disease;

(3) those developing disease intermediate between (1) and (2).

\footnotetext{
* Mary Scharlieb Research Student, University of London.
}

In such an experiment the dosage of bacilli entering the respiratory system is unknown, but when the resistance to a standard dose of tubercle bacilli was tested the rabbit families fell into the same three groups as with natural infection. From these experiments it appears that families with different degrees of resistance can be created by inbreeding and that the differences can be maintained through several generations. It must be noted, however, that marked differences in individual resistance were always present, and that the level of resistance of a particular family could be gauged only by the percentage of survivors in each group exposed to infection. Further, when members of the various families were exposed to large doses of bacilli, these differences were obliterated and all the rabbits succumbed in 5 to 6 weeks.

In human beings, Pearson (1907) found that when both parents were tuberculous 57 per cent. of the offspring had pulmonary tuberculosis, whereas only 29 per cent. of the offspring developed pulmonary tuberculosis when only one parent was tuberculous. Pearson dealt only with pulmonary tuberculosis and his selection of families was probably unrepresentative, since 22 per cent. of the offspring developed pulmonary tuberculosis when neither parent was tuberculous. He collected his information by questioning 383 patients in a sanatorium, all of whom had pulmonary tuberculosis and were aged 20 or over. Such a method is of dubious value. Unpleasant facts about one's family may be readily forgotten and parents sometimes take great care to conceal from their children that they have ever suffered from tuberculosis. Pope (ed. and rev. Pearson, 1908) considered that they had disposed of the view that infection plays a dominant role in the aetiology of tuberculosis by comparing the frequency with which non-tuberculous marital partners contracted tuberculosis from the spouse, with the frequency with which children contracted the disease from tuberculous parents. Such a comparison does not take into consideration the differing incidence of the disease in different age groups (Springett, 1952), and their conclusions are, therefore, invalid. 
The effect on household associates of exposure to sputum-positive cases is well known (Downes, 1935; Grenville-Mathers and Trenchard, 1953; Zeidberg, Dillon, and Gass 1954). Wolff and Ciocco (1942) analysed the death records of 968 husbands and wives and 968 brothers and sisters, one of whom was also a spouse of the former group. They found a distinct association for death from tuberculosis among both groups. They considered that the former was due to infection, but argued that siblings are not in such close contact with the patient and that the association for siblings pointed to the effect of an hereditary factor. Puffer (1944) found that consorts exposed to an open case of pulmonary tuberculosis frequently developed manifest tuberculosis. The risk was greater where the consorts came from families believed to be susceptible because of disease in parents or siblings. In the children of tuberculous persons, the disease was found as frequently in those who had not been exposed to the parent when he had the disease, as in those exposed to risk in the household. She presumed from this that the children of tuberculous parents were susceptible to the disease.

More definite evidence has come from twin studies. Thus Kallmann and Reisner (1943) found that, for monozygotic twins, there was a high probability of both developing tuberculosis. In this context twins cannot be regarded as typical of the population as a whole. Kallmann and Reisner also found that the chance of developing tuberculosis increased in strict proportion to the degree of blood relationship to a tuberculous index case, but their method of analysis is not clear.

We therefore lack definite evidence that an hereditary factor plays a predominant part in the development of tuberculosis in humans. On the other hand, the marked influence of environment in the broad sense, as governed by economic conditions, is now clearly established in the development of the disease. It is more common in poorer-class areas and in over-crowded housing conditions. Benjamin (1953) has shown for the London boroughs a high association of mortality and morbidity with the proportion of occupied and retired men in Social Class V and with the density of housing (persons per room), but he found it impossible to isolate statistically the separate aetiological influences constituting environment. Stein (1954) made a comparison between Birmingham and Glasgow, where the death rates from tuberculosis and housing conditions as indicated by available rooms per household are widely different. She also pointed out that the deaths in Glasgow increased as the rooms per household decreased.
For an evaluation of the relative importance of the soil and the seed in the aetiology of tuberculosis, analyses considering both domiciliary exposure to disease and the family relationship of the members of the household are needed. It seems justifiable to presume that members of the same household usually have approximately the same standard of living. With environment a common factor, heredity and closeness of contact become the main variables. If heredity is pre-eminent in the pathogenesis of tuberculosis, we should expect more cases in the blood relatives of the index case than in the other domiciliary contacts.

\section{METHOD}

At the Edgware and Harrow Chest Clinics great attention has always been paid to the examination of all domiciliary contacts of notified tuberculous cases. These contacts comprise both the blood relatives of the index case and those who are not blood relatives. The former include fathers, mothers, sons, daughters, brothers, and sisters; the latter include brothers-in-law, sisters-in-law, and friends or lodgers living as members of the household. Husbands and wives are not blood relations but stand in a special position so far as contact is concerned and require separate consideration.

For the investigation here reported we have used only those index cases diagnosed as tuberculous in Middlesex, and have excluded already diagnosed patients transferred in from other administrative areas. Altogether there were 2,330 index cases; their ages and type of disease are given in Table I. We have dealt with 6,537 contacts of these index cases. As only 32 grandparents of the index case were available, these were excluded from the analysis. The presence or absence of disease in contacts was determined by clinical and radiological examination of the

TABLE I

AGE DISTRIBUTION AND TYPE OF DISEASE IN 2,330 INDEX CASES OF TUBERCULOSIS

\begin{tabular}{|c|c|c|c|c|c|}
\hline \multirow{2}{*}{$\underset{\substack{\text { Age } \\
\text { (yroup }}}{\text { (yrs) }}$} & \multirow{2}{*}{$\begin{array}{c}\text { Pleural } \\
\text { Effusion }\end{array}$} & \multirow{2}{*}{$\begin{array}{c}\text { Non- } \\
\text { Respiratory } \\
\text { Tuberculosis }\end{array}$} & \multicolumn{2}{|c|}{$\begin{array}{l}\text { Respiratory } \\
\text { Tuberculosis }\end{array}$} & \multirow[b]{2}{*}{ Totals } \\
\hline & & & $\begin{array}{l}\text { Sputum- } \\
\text { Negative }\end{array}$ & $\begin{array}{l}\text { Sputum- } \\
\text { Positive }\end{array}$ & \\
\hline $\begin{array}{c}0-4 \\
5-9 \\
10-14 \\
15-24 \\
25-34 \\
35-44 \\
45-54 \\
55-64 \\
65 \text { and } \\
\text { Over }\end{array}$ & $\begin{array}{r}3 \\
11 \\
18 \\
98 \\
23 \\
10 \\
3 \\
2 \\
-\end{array}$ & $\begin{array}{r}11 \\
17 \\
17 \\
25 \\
14 \\
12 \\
3 \\
1 \\
-\end{array}$ & $\begin{array}{r}17 \\
34 \\
30 \\
258 \\
191 \\
102 \\
60 \\
34 \\
\\
21\end{array}$ & $\begin{array}{r}1 \\
3 \\
21 \\
395 \\
338 \\
248 \\
176 \\
101 \\
32\end{array}$ & $\begin{array}{r}32 \\
65 \\
86 \\
776 \\
566 \\
372 \\
242 \\
138 \\
\\
53\end{array}$ \\
\hline Totals & 168 & 100 & 747 & 1,315 & 2,330 \\
\hline
\end{tabular}


individuals concerned and not by the statements of the patient. Only those who were actually in contact with and living in the same household as the index cases were considered. Thus lodgers who did not live with the family and married children living in their own part of the house as a separate flat were not considered to be members of that household. By reason of the nature of the area in which the survey was undertaken, all the patients and contacts lived in conditions of approximately the same standard. Post-war conditions of crowding caused many households to shelter both relatives and non-relatives of the index cases. The area, comprising the boroughs of Harrow and Hendon and part of the borough of Wembley (population circa 450,000 ), is almost entirely residential, a large proportion of the houses being of the modern three-bedroom, semidetached villa type, occupied by artisans and members of the lower middle-class.

The contacts were classified by age and by relationship to the index case (i.e. "son", "daughter", "father", etc., where specific blood-relationship existed; "spouse", and "non-relative" where no blood-relationship existed).

All tuberculous contacts were further sub-divided into those found to have tuberculosis when first seen (usually within 2 months of the index case being diagnosed), and those developing tuberculosis later. The period of observation of all contacts was also noted.

Where there were two or more cases of tuberculosis in a household, the patient first diagnosed was regarded as the index case, but if a child and an adult were found within a few weeks of each other, the adult was regarded as the index case. All the index cases considered were first diagnosed as tuberculous while living in the area under review.

\section{RESUltS}

In comparing the incidence of tuberculosis at first examination in the various groups of contacts, account was taken of their different age structure; the expected numbers of cases were calculated by applying age-specific rates for all contacts combined to those at risk at each age in the different groups. This was done separately for male and female contacts. The following age groups were used for each sex: $0-14,15-24,25-34,35-49,50$ and over.

In the same way annual attack rates were calculated for each age group, and expected cases in the different groups were obtained by applying these age-specific rates for all contacts to those in continued contact with the index case. The results are summarized in Table II. Incidence on and after diagnosis of the index case must be regarded as complementary, since whether the disease develops in a contact before the diagnosis of the index case depends on the length of time that the index case remains undiscovered. Attention should therefore be focused on the final column of Table II, which relates to total incidence.

The observed number of tuberculous individuals did not exceed the expected number to a statistically significant extent for any group of contacts except wives. There is thus no evidence of a greater susceptibility to disease in blood relatives. Moreover, it must be noted that the groups of contacts have been arranged in Table II in an order determined by the degree of infectiousness of the index

TABLE II

SECONDARY CASES OF TUBERCULOSIS OCCURRING AMONGST THE 6,537 CONTACTS

\begin{tabular}{|c|c|c|c|c|c|c|c|c|c|c|c|}
\hline \multirow[b]{3}{*}{$\begin{array}{c}\text { Sex of } \\
\text { Contact }\end{array}$} & \multirow{3}{*}{\multicolumn{2}{|c|}{$\begin{array}{c}\text { Relationship of } \\
\text { Contact to Index Case }\end{array}$}} & \multirow[b]{3}{*}{$\begin{array}{l}\text { No. of } \\
\text { Contacts }\end{array}$} & \multirow{3}{*}{$\begin{array}{c}\text { Per cent. } \\
\text { of Related } \\
\text { Index Cases } \\
\text { who were } \\
\text { ever Sputum- } \\
\text { Positive }\end{array}$} & \multicolumn{6}{|c|}{ Incidence of Tuberculosis } & \multirow[b]{3}{*}{$\begin{array}{c}\text { Ratio of } \\
\text { Total } \\
\text { Observed } \\
\text { to Total } \\
\text { Expected }\end{array}$} \\
\hline & & & & & \multicolumn{3}{|c|}{ Present when First Seen } & \multicolumn{3}{|c|}{ Developed Later } & \\
\hline & & & & & $\begin{array}{l}\text { Number } \\
\text { Observed }\end{array}$ & $\begin{array}{c}\text { Number } \\
\text { Expected } \\
\text { (on overall- } \\
\text { sex-age- } \\
\text { specific } \\
\text { rates) }\end{array}$ & $\begin{array}{l}\text { Ratio of } \\
\text { Observed } \\
\text { to } \\
\text { Expected }\end{array}$ & $\begin{array}{l}\text { Number } \\
\text { Observed }\end{array}$ & \begin{tabular}{|c|} 
Number \\
Expected \\
(on overall- \\
sex-age- \\
specific \\
rates)
\end{tabular} & $\begin{array}{c}\text { Ratio of } \\
\text { Observed } \\
\text { to } \\
\text { Expected }\end{array}$ & \\
\hline Male & $\begin{array}{l}\text { Grandson } \\
\text { Son .. } \\
\text { No relative } \\
\text { Husband.. } \\
\text { Nephew .. } \\
\text { Brother . } \\
\text { Father .. }\end{array}$ & $\begin{array}{l}\cdots \\
\cdots \\
\cdots \\
\cdots \\
\cdots\end{array}$ & $\begin{array}{r}50 \\
958 \\
336 \\
444 \\
95 \\
599 \\
533\end{array}$ & $\begin{array}{l}86 \\
79 \\
66 \\
64 \\
60 \\
50 \\
41\end{array}$ & $\begin{array}{r}3 \\
43 \\
15 \\
15 \\
3 \\
30 \\
11\end{array}$ & $\begin{array}{r}2 \cdot 6 \\
48 \cdot 8 \\
12 \cdot 1 \\
12 \cdot 4 \\
5 \cdot 1 \\
28 \cdot 0 \\
12 \cdot 0\end{array}$ & $\begin{array}{c}(1 \cdot 2) \\
0.9 \\
1 \cdot 2 \\
1 \cdot 2 \\
(0 \cdot 6) \\
1 \cdot 1 \\
0.9\end{array}$ & $\begin{array}{r}0 \\
17 \\
1 \\
5 \\
0 \\
9 \\
1\end{array}$ & $\begin{array}{r}0 \cdot 4 \\
16 \cdot 5 \\
1 \cdot 7 \\
5 \cdot 7 \\
0 \cdot 7 \\
4 \cdot 5 \\
3 \cdot 4\end{array}$ & $\begin{array}{c}(-) \\
1 \cdot 0 \\
(0 \cdot 6) \\
0 \cdot 9 \\
(-) \\
2 \cdot 0 \\
(0 \cdot 3)\end{array}$ & $\begin{array}{l}(1 \cdot 0) \\
0 \cdot 9 \\
1 \cdot 2 \\
1 \cdot 1 \\
(0 \cdot 5) \\
1 \cdot 2 \\
0 \cdot 8\end{array}$ \\
\hline Female & $\begin{array}{l}\text { Wife } \\
\text { No relative } \\
\text { Niece .. } \\
\text { Daughter } \\
\text { Sister . } \\
\text { Granddaughter } \\
\text { Mother ... }\end{array}$ & $\begin{array}{l}\cdots \\
\cdots \\
\cdots \\
\cdots \\
\cdots\end{array}$ & $\begin{array}{r}668 \\
339 \\
87 \\
936 \\
707 \\
36 \\
749\end{array}$ & $\begin{array}{l}78 \\
70 \\
64 \\
63 \\
51 \\
47 \\
43\end{array}$ & $\begin{array}{r}25 \\
12 \\
3 \\
38 \\
20 \\
2 \\
9\end{array}$ & $\begin{array}{r}15 \cdot 3 \\
11 \cdot 0 \\
3 \cdot 4 \\
37 \cdot 9 \\
29 \cdot 8 \\
1 \cdot 4 \\
10 \cdot 0\end{array}$ & $\begin{array}{c}1 \cdot 6 \\
1 \cdot 1 \\
(0 \cdot 9) \\
1 \cdot 0 \\
0 \cdot 7 \\
(1 \cdot 4) \\
0 \cdot 9\end{array}$ & $\begin{array}{r}13 \\
1 \\
1 \\
8 \\
15 \\
15 \\
0 \\
3\end{array}$ & $\begin{array}{r}13 \cdot 9 \\
1 \cdot 9 \\
0 \cdot 3 \\
12 \cdot 5 \\
8 \cdot 2 \\
0 \cdot 2 \\
3 \cdot 9\end{array}$ & $\begin{array}{c}0.9 \\
(0.5) \\
(3 \cdot 3) \\
0.6 \\
1 \cdot 8 \\
(-) \\
(0.8)\end{array}$ & $\begin{array}{c}1 \cdot 3 \\
1 \cdot 0 \\
(1 \cdot 1) \\
0 \cdot 9 \\
0 \cdot 9 \\
(1 \cdot 3) \\
0 \cdot 9\end{array}$ \\
\hline
\end{tabular}


case as assessed by sputum state. Ignoring the groups with very small numbers (bracketed rates) and considering both sexes together, there is at least a suggestion that the relative incidence of tuberculosis exhibits a similar gradient. In the Figure the ratios of observed cases to expected cases have been plotted against the sputum-positivity of the index cases. The straight line is a "least squares" fit to the whole data of Table II $(y=0.00423 X+0.742)$. The main departures from this gradient are wives, brothers, sons, and daughters, and of these the quality of contact offers partial explanation. It can be presumed, for example, that the probably high degree of contact between spouses increases the effective infectiousness of the index case.

Table III (opposite) gives, by age groups for the main groups of contacts, the percentage in contact with a sputum-positive index case. In general, irrespective of the degree of infection to which they are exposed, females do not often break down after age 35. This Table also shows the relative disadvantages of wives aged 15 to 24 years and husbands aged 25 to 34 years. The closer degree of contact has already been noted as increasing the relative infectivity of the index case. Non-relatives do not appear to have any special advantage over blood relations.

It appeared possible that the effect of any hereditary factor may have been swamped by the great influence of environment, and the data were therefore analysed using only houses in which two or more cases of tuberculosis had occured (Table IV, opposite).

These were chosen as being likely to be biased, since they would probably contain individuals with a

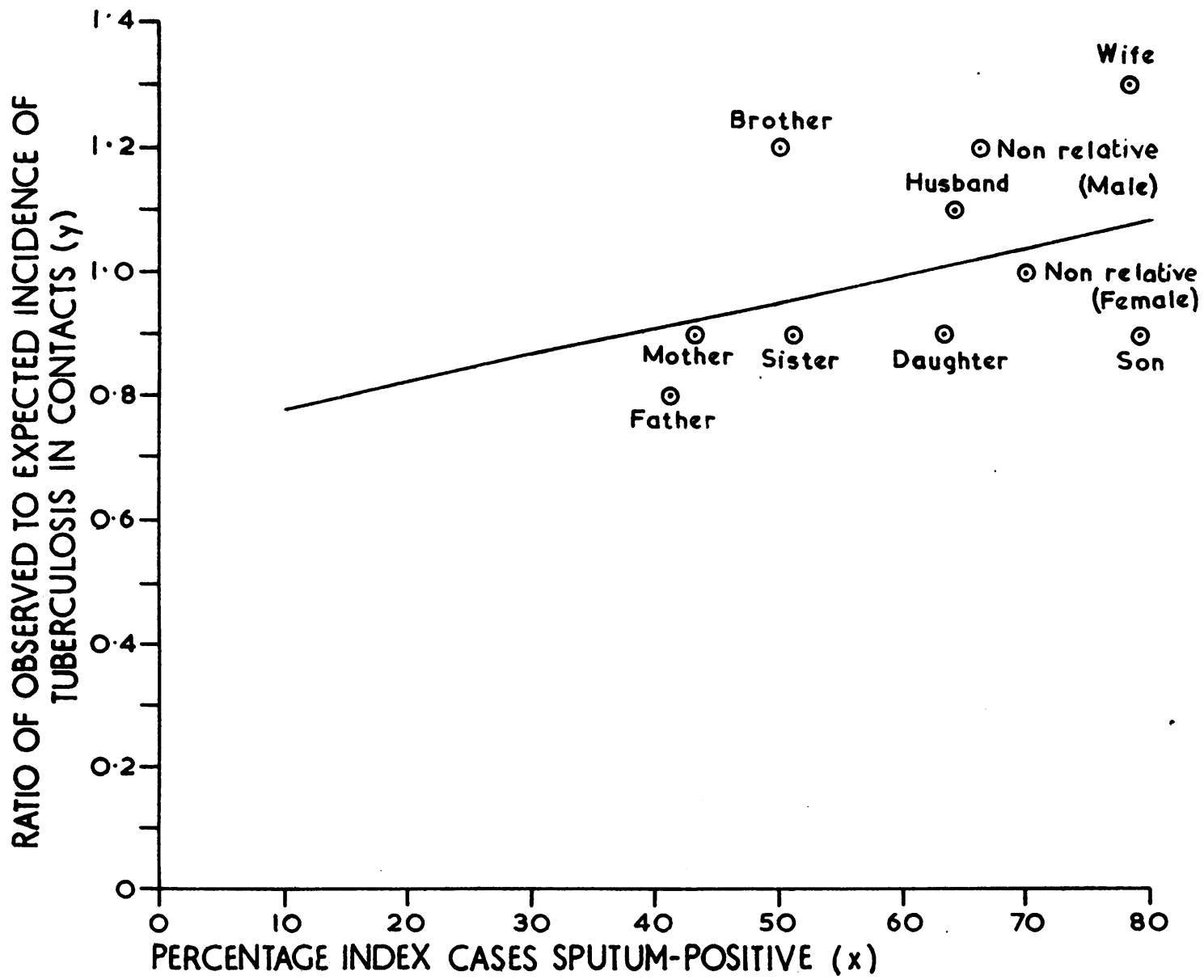

FIGURE.-Ratios of observed to expected incidence of tuberculosis in contacts plotted against sputum-positivity of index cases. 
TABLE III

INCIDENCE OF DISEASE IN MAIN GROUPS OF CONTACTS WHEN FIRST SEEN

\begin{tabular}{|c|c|c|c|c|c|c|c|}
\hline \multirow{3}{*}{$\begin{array}{c}\text { Age } \\
\text { Group } \\
\text { (yrs) }\end{array}$} & \multirow{3}{*}{$\begin{array}{l}\text { Percentages } \\
\text { Affected with } \\
\text { Tuberculosis } \\
\text { and in Contact } \\
\text { with a Sputum- } \\
\text { Positive Case }\end{array}$} & \multicolumn{6}{|c|}{ Relationship of Contacts } \\
\hline & & \multicolumn{3}{|c|}{ Male } & \multicolumn{3}{|c|}{ Female } \\
\hline & & $\begin{array}{l}\text { Non- } \\
\text { rela- } \\
\text { tive }\end{array}$ & $\begin{array}{c}\text { Other } \\
\text { rela- } \\
\text { tive }\end{array}$ & $\begin{array}{l}\text { Hus- } \\
\text { band }\end{array}$ & $\begin{array}{l}\text { Non- } \\
\text { rela- } \\
\text { tive }\end{array}$ & $\begin{array}{c}\text { Other } \\
\text { rela- } \\
\text { tive }\end{array}$ & Wife \\
\hline \multirow{2}{*}{$0-14$} & Affected & $4 \cdot 8$ & $5 \cdot 4$ & - & $6 \cdot 3$ & $3 \cdot 8$ & - \\
\hline & In Contact ... & 69 & 57 & - & 62 & 53 & - \\
\hline \multirow{2}{*}{$15-24$} & Affected & $18 \cdot 8$ & $3 \cdot 4$ & $(2 \cdot 4)$ & $(5 \cdot 1)$ & $3 \cdot 9$ & $9 \cdot 8$ \\
\hline & In Contact ... & 71 & 63 & 36 & 77 & 65 & 72 \\
\hline \multirow{2}{*}{$25-34$} & Affected & $(1 \cdot 2)$ & $3 \cdot 4$ & $4 \cdot 1$ & $5 \cdot 5$ & $3 \cdot 7$ & $7 \cdot 2$ \\
\hline & In Contact .. & 61 & 58 & 60 & 73 & 49 & 78 \\
\hline \multirow{2}{*}{$35-39$} & Affected & $(1 \cdot 4)$ & $1 \cdot 6$ & $2 \cdot 9$ & 0 & 0.9 & $1 \cdot 7$ \\
\hline & In Contact .. & 62 & 54 & 65 & 66 & 62 & 78 \\
\hline \multirow{2}{*}{$\begin{array}{l}50 \text { and } \\
\text { Over }\end{array}$} & Affected & 0 & $2 \cdot 7$ & $3 \cdot 4$ & 0 & 0.6 & $1 \cdot 8$ \\
\hline & In Contact .. & 69 & 54 & 70 & 72 & 53 & 79 \\
\hline
\end{tabular}

(Rates in brackets based on very small numbers of cases)

lowered resistance to disease. But these households proved to be mainly those in which the index case was sputum-positive. On the whole, Table IV tells the same story as Table II, with the degree of infectivity of the index case and the closeness of contact tending to be more important than blood relationship.

TABLE IV

HOUSES WITH TWO OR MORE CASES

\begin{tabular}{|c|c|c|c|c|}
\hline $\begin{array}{c}\text { Sex of } \\
\text { Con- } \\
\text { tact }\end{array}$ & $\begin{array}{l}\text { Relation- } \\
\text { ship of } \\
\text { Contact to } \\
\text { Index Case }\end{array}$ & $\begin{array}{l}\text { Number } \\
\text { of } \\
\text { Contacts }\end{array}$ & $\begin{array}{l}\text { Per cent. of } \\
\text { Related } \\
\text { Index Cases } \\
\text { ever } \\
\text { Sputum- } \\
\text { Positive }\end{array}$ & $\begin{array}{l}\text { Ratio of Total } \\
\text { Observed Cases of } \\
\text { Tuberculosis to } \\
\text { Total Expected } \\
\text { during Period of } \\
\text { Observation }\end{array}$ \\
\hline Male & $\begin{array}{l}\text { Son } \\
\text { Husband } \\
\text { Nephew } \\
\text { No } \\
\text { relative } \\
\text { Brother ... } \\
\text { Grandson } \\
\text { Father .. }\end{array}$ & $\begin{array}{r}171 \\
61 \\
31 \\
77 \\
127 \\
8 \\
69\end{array}$ & $\begin{array}{l}90 \\
86 \\
84 \\
\\
78 \\
77 \\
75 \\
71\end{array}$ & $\begin{array}{l}1 \cdot 09 \\
1 \cdot 3 \\
(0 \cdot 3) \\
0.9 \\
1 \cdot 0 \\
(0 \cdot 2) \\
0.9\end{array}$ \\
\hline Female & 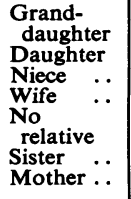 & $\begin{array}{r}9 \\
138 \\
35 \\
107 \\
\\
86 \\
149 \\
94\end{array}$ & $\begin{array}{r}100 \\
92 \\
91 \\
85 \\
\\
80 \\
75 \\
73\end{array}$ & $\begin{array}{l}(0.8) \\
1 \cdot 1 \\
(0.4) \\
1.4 \\
0.7 \\
0.8 \\
1.0\end{array}$ \\
\hline
\end{tabular}

(Rates in brackets based on very small numbers of cases)

\section{Discussion}

The results presented here differ from those eported by Puffer, Zeidberg, Dillon, Gass, and
Hutcheson (1952) and Kallmann and Reisner (1943), in which the attack rates for close relatives (parents, siblings, and children) were found to be higher than for other contacts. Puffer and others (1952) and Zeidberg and others (1954) also found that the household associates were most liable to develop clinical disease during infancy, early childhood, and early adult life. We found, on the other hand, that the risk of developing clinical disease appears to be related to the degree of infectivity of the index case (except that females do not tend to break down often after age 35). This is in accord with the commonly accepted findings in Great Britain.

Pulmonary tuberculosis in adults may be the result either of a recent primary infection or of a re-infection, which may be either endogenous or, more probably, exogenous (Willis, 1925; Krause, 1926). If the re-infection be mainly exogenous, the degree of exposure of any contacts must clearly be a factor in the development of tuberculosis. The Prophit survey (Daniels, Ridehalgh, Springett, and Hall, 1948) found that only when the degree of exposure to infection was sufficienctly great and the number of infections sufficiently high, did the morbidity in the initially tuberculin-negative reactors in the survey begin to exceed that in the initially tuberculin-positive reactors.

Lurie (1941), in his experimental work in rabbit families, found that, although there was an hereditary transmissible factor in resistance to tuberculosis, the differences between the various families were obliterated when exposure to infection was high.

The annual attack rates in our survey were higher than those in surveys reported from the United States of America. It seems probable, therefore, that in the conditions which have prevailed in our chest clinic areas during the past few years the possible influence of any hereditary factor has been obliterated by the high degree of infectivity to which the contacts have been exposed. In this investigation we have dealt only with the household associates of notified cases of tuberculosis (the great majority being respiratory tuberculosis). Our usual criteria for notification of a case of respiratory tuberculosis are the presence of a positive sputum, radiological evidence of cavitatory disease, or spreading infiltration on serial films, so that many of our index cases classified as sputumnegative may well have been infectious. Our findings; like those of the Prophit survey, suggest therefore that (in one urban area at least) environmental factors and the degree of exposure to infection are of predominant importance in the development of tuberculosis. 


\section{SUMMARY}

An investigation into the relative importance of heredity and environment is based on the 6,537 domiciliary contacts of 2,330 cases of tuberculosis. The incidence of disease in blood-relations, spouses, and non-relatives was compared after standardization of age-specific rates. No effective hereditary factor could be found, but the degree of infectivity and the closeness of contact with the index case seemed to be related to the incidence of tuberculous disease in contacts.

We wish to thank the Hendon Group Hospital Management Committee for help towards the clerical expenses.

\section{REFERENCES}

Benjamin, B. (1953). Brit. J. Tuberc., 47, 4.

Benjamin, B. (1953). Brit. J. Tuberc., 47, 4 . "Tuberculosis in Young Adults". Report on the Prophit Tuberculosis Survey 1935-1944. Lewis, London.

Downes, J. (1935). Amer. J. Hyg., 22, 731

Grenville-Mathers, R., and Trenchard, H. J. (1953). Proc. roy. Soc. Med., 46, 809.

Kallmann, F, J. and Reisner, D. (1943). Amer. Rev. Tuberc, 47, 549.

Krause, A. K. (1926). Ibid., 14, 211.

Lurie, M. B. (1941). "Heredity, Constitution, and Tuberculosis. An Experimental Study". Ibid., 44, Suppl. to No. 3.

Pearson, K. (1907). "A First Study of the Statistics of Pulmonary Tuberculosis". Drapers' Company Research Memoirs, Studies in National Deterioration, 2. Dulau, London.

Pope, E. G. (Ed. and rev. Pearson, K.. 1908). "A Second Study of the Statistics of Pulmonary Tuberculosis: Marital Infection". Ibid., 3. Cambridge University Press, London.

Puffer, R. R. (1944). "Familial Susceptibility to Tuberculosis". Harvard University Press, Cambridge, Mass.

_, Zeidberg, L. D., Dillon, A., Gass, R. S., and Hutcheson, R. H. (1952). Amer. Rev. Tuberc., 65, 111.

Springett, V. H. (1952). Lancet, 1, 575.

Stein, L. (1954). Tubercle, 35, 195.

Willis, H. S. (1925). Amer. Rev. Tuberc., 11, 439.

Wolff, G., and Ciocco, A. (1942). Ibid., 46, 142.

Wright, S., and Lewis, P. A. (1921). Amer. Naturalist, 55, 20.

Zeidberg, L. D., Dillon, A., and Gass, R. S. (1954). Amer. Rev. Tuberc., 70, 1009. 